\title{
ENHANCEMENT OF THE ANTIDIABETIC EFFECT OF GLICLAZIDE BY THE ANTIPEPTIC DRUG OMEPRAZOLE IN ALLOXAN-INDUCED DIABETIC RATS
}

\author{
MAHMOUD H. ABDELRAHIM ${ }^{1}$; SAFWAT A. MANGOURA ${ }^{1}$; SOTOHY A. SOTOHY ${ }^{2}$; \\ SARY KH. ABDELGHAFAR ${ }^{3}$ and ASMAA M. SADEK ${ }^{4}$ \\ ${ }^{1}$ Department of Pharmacology, Faculty of Medicine, Assiut University. \\ ${ }^{2}$ Department of Animal \& Poultry Hygiene, Faculty of Veterinary Medicine, Assiut University. \\ ${ }^{3}$ Department of Pathology, Faculty of Veterinary Medicine, Assiut University. \\ ${ }^{4}$ Department of Pharmacology, Faculty of Veterinary Medicine, New Valley University.
}

Received: 25 August 2019; Accepted: 5 September 2019

\begin{abstract}
Introduction: Diabetes mellitus (DM) is a global emerging disease with progressive incidence worldwide. Diabetic patients have a higher incidence of peptic ulcer disease than the non-diabetic population. So, diabetic patients treated with oral antidiabetic drugs, as gliclazide, may be also treated with antipeptic ulcer drugs, as omeprazole. Aim of the Study: Evaluation of the possible drug-drug interactions between gliclazide and omeprazole in alloxan-induced diabetic rats. Materials and Methods: The study was done on 40 adult male albino rats (250-300 gm) classified into five groups. Diabetes was induced in group II, III, IV \&V using alloxan monohydrate while group I was left as a negative control. Group II received no treatment, group III received gliclazide, group IV received omeprazole, while group V received combination of gliclazide and omeprazole. After the end of the experiment, rats were sacrificed and blood samples were collected for measurement of glucose, insulin, total antioxidant capacity (TAC), tumor necrosis factor- $\alpha$ (TNF $\alpha$ ) level. Also, histopathological study of the pancreas specimens was done. Results: diabetic rats showed significant increase in serum glucose level compared to normal rats. Treatment with gliclazide, omeprazole or combination of them had significant decrease in high serum glucose level. Serum insulin level in diabetic rats had significant decrease compared to normal rats. While, Treatment with gliclazide, omeprazole or combination of them had significant increase in its low level. Besides, diabetes in rats caused significant decrease in TAC compared to normal rats. Treatment with gliclazide, omeprazole or combination of them had significant increase in its low level. Regarding TNF- $\alpha$, alloxan-induced diabetes in rats caused significant elevation in its level compared to normal rats. Treatment with gliclazide, omeprazole and combination of gliclazide and omeprazole caused significant reduction in its high level. Conclusion: The antidiabetic action of gliclazide was enhanced by omeprazole.
\end{abstract}

Key word: Alloxan monohydrate, Diabetes mellitus, Gliclazide, Omeprazole, Peptic ulcer.

\section{INTRODUCTION}

Diabetes mellitus is a disease characterized by hyperglycemia, depletion of antioxidants and alteration in lipid metabolism (Jay et al., 2006). Diabetes is characterized by increased the generation of Reactive oxygen species (ROS) and decreased antioxidant levels in the body (Owu et al., 2012). Moreover, under chronic hyperglycemia, there is an increase in TNF- $\alpha$ production and oxidative stress which mediate diabetic complications (Kandhare et al., 2012).

Diabetic patients have a higher incidence of peptic ulcer disease than the non-diabetic population (Tseng

Corresponding author: Dr. Asmaa M. Sadek E-mail address: asmaamsadek92@gmail.com

Present address: Department of Pharmacology, Faculty of Veterinary Medicine, New Valley University et al., 2012). Diabetes is associated with an increased prevalence of gastrointestinal tract symptom and susceptibility to acute gastric injury and impaired ulcer healing (Takehara et al., 1997).

Peptic ulcer is a break in the lining of the stomach, first part of the small intestine and the lower esophagus (Alshammari et al., 2018).

Omeprazole is an example of proton pump inhibitors (PPIs). It blocks gastric acid secretion by irreversibly inhibiting the hydrogen/potassium adenosine triphosphatase $\left(\mathrm{H}^{+} / \mathrm{K}^{+}\right.$ATPase $)$of the gastric parietal cell (Morjan et al., 2013).

Gliclazide is sulfonylurea used for the treatment of type 2 diabetes mellitus (T2DM). It act by binding to the $\beta$-cell sulfonylurea receptor that blocks the ATPsensitive potassium channels, resulting in a decrease in potassium efflux leads to opening of voltage- 
dependent calcium channels, resulting in exocytosis of insulin containing secretory granules (Inzucchi et al., 2012). It is preferred in therapy because of its selective inhibitory activity towards $\mathrm{K}^{+} \mathrm{ATP}$ channels, antioxidant property and low incidence of producing severe hypoglycemia (Mastan and Kumar, 2010).

\section{MATERIALS AND METHODS}

\section{I- Materials}

\section{Animals:}

Forty adult male Wistar albino rats weighing 250-300 grams were purchased from the animal house, Faculty of Veterinary Medicine, Assuit University. The animals were transmitted to Faculty of Veterinary Medicine, New Valley University. They were housed under standardized environmental conditions, fed with standard chow diet and tap water ad libitum and kept for 2 weeks to adapt the laboratory conditions before starting the experiment. All the animal experiments were conducted in accordance with the guide of the National Institutes of Health (NIH 1985) for the care of laboratory animals.

\section{Chemicals and kits:}

Alloxan monohydrate was purchased from LOBA chemie (Mumbai, India), gliclazide and omeprazole were purchased from AK Scientific (Union City, U.S.A.), carboxymethylecellulose (CMC) was purchased from SD Fine-Chem LTD. (Mumbai, India), glucose assay kit and TAC kit were purchased from Biodiagnostic (Egypt), insulin ELISA kit was purchased from Immunospec Corporation (USA), TNF- $\alpha$ ELISA kit was purchased from Becton (USA).

\section{II- Methods}

Induction of diabetes mellitus: Rats were treated with a single dose of freshly prepared solution of alloxan monohydrate $(100 \mathrm{mg} / \mathrm{kg})$ intraperitoneally (IP) after overnight fasting to induce diabetes (Mastan et al., 2009). During the first $24 \mathrm{~h}$ of diabetes induction, alloxan treated animals were allowed to drink 5\% glucose solution to overcome alloxaninduced hypoglycemia (Abdel Aziz et al., 2017).

To confirm the induction of diabetes mellitus: The blood glucose of each animal was measured using the glucometer. Diabetes was confirmed 48 hours after alloxan injection. Rats with blood glucose levels of $250 \mathrm{mg} / \mathrm{dl}$ and above were considered diabetic and selected for study (Ige and Adewoye, 2013).

\section{Experimental design:}

Animal groups:

Animals were randomly divided into five groups (8 animals per group):

Group I (Negative control group): The rats were injected IP with an equivalent volume of normal saline.

Group II (positive control group): The rats were injected IP with alloxan $(100 \mathrm{mg} / \mathrm{kg})$ dissolved in normal saline to induce DM. Rats were received an equivalent volume of $0.5 \% \mathrm{CMC}$ solution orally by gastric tube once daily for 28 consecutive days.

Group III (Effect of gliclazide on diabetic rats): Diabetic rats were received gliclazide at a dose 10 $\mathrm{mg} / \mathrm{kg}$ suspended in $1 \mathrm{ml}$ of $0.5 \%$ CMC solution orally by a gastric tube once daily for 28 consecutive days.

Group IV (Effect of omeprazole on diabetic rats): Diabetic rats were received omeprazole at a dose 20 $\mathrm{mg} / \mathrm{kg}$ suspended in $1 \mathrm{ml}$ of $0.5 \%$ CMC solution orally by a gastric tube once daily for 28 consecutive days.

Group V (Effect of the combined administration of omeprazole and gliclazide on diabetic rats): Diabetic rats were received omeprazole at a dose 20 $\mathrm{mg} / \mathrm{kg}$ and gliclazide at a dose $10 \mathrm{mg} / \mathrm{kg}$ orally by a gastric tube daily for 28 consecutive days.

\section{Sample collection:}

\section{Serum samples:}

The animals after overnight fasting were anaesthetized with ether by placing the rat in an anesthetic box filled with ether vapor, which was maintained by periodically applying liquid ether to a cotton wool on the base of the box. When the surgical stage of anesthesia was reached (judged by loss of withdrawal reflexes) the animal was removed and placed on a table. The blood was collected from the retro-orbital plexus in micro centrifuge tube. The collected blood was allowed to clot in an upright position at room temperature for an hour; and then refrigerated for further an hour for clot retraction. Clear serum was separated by centrifugation at 3000 r.p.m. for 10-15 minutes and then collected in Eppendorf's tubes processed directly for glucose determination, then kept in deep freezer at $-20^{\circ} \mathrm{C}$ for subsequent biochemical analysis (Hussein et al., 2015).

\section{Tissue sample:}

After blood samples collection the rats were sacrificed. The Pancreas was removed, rinsed in icecold $0.9 \%$ sodium chloride solution and prepared for histopathological evaluation (Hussein et al., 2015).

\section{Experimental procedure:}

1) Determination of serum glucose level:

Serum glucose level was estimated according to the enzymatic colorimetric method (Trinder, 1969). 


\section{2) Determination of serum insulin level:}

Serum insulin levels were estimated by rat/mouse ELISA kit (Millipore) according to manufacture's protocol (Zhang et al., 2008).

\section{3) Determination of serum TAC:}

Serum TAC was determined using TAC colorimetric kit according to the manufacture's protocol (Koracevic et al., 2001).

\section{4) Determination of serum TNF $\alpha$ :}

Serum TNF- $\alpha$ level was estimated by ELISA kit according to manufacture's protocol (Beyaert and Fiers, 1998).

\section{5) Histopathological examination:}

A small specimen of pancreas was fixed in $10 \%$ neutral buffered formalin solution for 24 hours and then washed by running water over night and dehydrated. The dehydrated samples were cleared in xylol for 6 hours. The specimens were placed in a crucible containing soft paraffin and kept in an oven at $56^{\circ} \mathrm{C}$ for 12 hours. The samples were then blocked in hard paraffin and cut into sections of about 5 microns in thickness. Then, the sections stained by hematoxylene and eosin and were examined under light microscopy at $200 \mathrm{X}$ magnification (DP72, Olympus) (D Bancroft and Stevens, 2018).

\section{Data management and statistical analysis:}

The data were presented as means \pm standard errors (SE) and analyzed by one-way analysis of variance (ANOVA). For the comparison of statistical significance between two groups, Student's unpaired t-test was used. A P-value of $<0.05$ was adopted as statistically significant. Data analysis was performed by using Graph Pad Prism 7 (Graph Pad software Inc., San Diego, USA).

\section{RESULTS}

1- Effect of gliclazide, omeprazole and their combination on serum glucose level of diabetic rats:

These results are given in Table (1) and graphically illustrated in Figure (1).

The results showed that, serum glucose level was significantly increased $(\mathrm{p}<0.001)$ in $+\mathrm{ve}$ control) in comparison with - ve control rats.

In diabetic rats treated with gliclazide $10 \mathrm{mg} / \mathrm{kg}$ orally for 28 consecutive days, serum glucose level was significantly decreased $(\mathrm{p}<0.001)$ in comparison with diabetic rats (+ve control)

On the other hand, serum glucose level in diabetic rats treated with omeprazole $20 \mathrm{mg} / \mathrm{kg}$ orally for 28 consecutive days was significantly decreased ( $\mathrm{p}<$ 0.001 ) in comparison with diabetic rats.

In diabetic rats treated with a combination of gliclazide $10 \mathrm{mg} / \mathrm{kg}$ and omeprazole $20 \mathrm{mg} / \mathrm{kg}$ orally for 28 consecutive days, serum glucose level was significantly decreased $(\mathrm{p}<0.001)$ in comparison with diabetic rats.

Table 1: Effect of gliclazide (10 mg/ $\mathrm{kg})$, omeprazole $(20 \mathrm{mg} / \mathrm{kg})$ and their combination on serum glucose level, serum insulin level, serum TAC, serum TNF- $\alpha$ level in diabetic rats.

\begin{tabular}{|c|c|c|c|c|c|}
\hline Parameter & $\begin{array}{l}\text { Negative } \\
\text { control }\end{array}$ & $\begin{array}{l}\text { Positive } \\
\text { control }\end{array}$ & $\begin{array}{l}\text { Gliclazide in } \\
\text { diabetic rats }\end{array}$ & $\begin{array}{l}\text { Omeprazole in } \\
\text { diabetic rats. }\end{array}$ & $\begin{array}{l}\text { Gliclazide+omeprazole } \\
\text { in diabetic rats }\end{array}$ \\
\hline $\begin{array}{l}\text { Serum glucose } \\
\quad(\mathrm{mg} / \mathrm{dl})\end{array}$ & $97.6 \pm 2.98$ & $360.4^{* * * *} \pm 2.73$ & 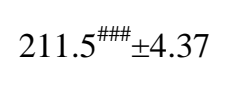 & 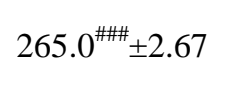 & $147.5^{\# \# \#} \pm 2.55$ \\
\hline $\begin{array}{l}\text { Serum insulin } \\
(\mu \mathrm{IU} / \mathrm{ml})\end{array}$ & $13.40 \pm 0.14$ & $5.07^{* * * *} \pm 0.05$ & $8.34^{\# \# \#} \pm 0.15$ & 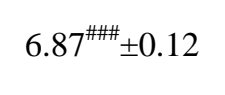 & $11.07^{\# \# \#} \pm 0.13$ \\
\hline $\begin{array}{l}\text { Serum TAC } \\
(\mathrm{Mm} / \mathrm{L})\end{array}$ & $1.69 \pm 0.027$ & $0.58^{* * *} \pm 0.019$ & $1.295^{\# \# \#} \pm 0.024$ & 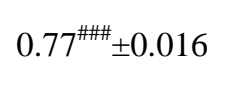 & 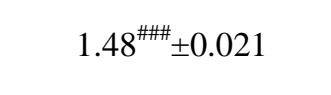 \\
\hline $\begin{array}{l}\text { Serum TNF- } \alpha \\
\quad(\mathrm{pg} / \mathrm{ml})\end{array}$ & $13.23 \pm 0.30$ & $91.80^{* * * * *} \pm 0.38$ & $31.82^{\# \# \#} \pm 0.40$ & 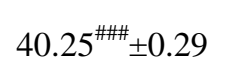 & $25.36^{\# \# \#} \pm 0.23$ \\
\hline
\end{tabular}

Data represent the mean \pm SE of each group $(n=8)$. $* * *$ : significant difference at $p<0.001$ in comparison with ve control. \#\#\#: significant difference at $\mathrm{p}<0.001$ in comparison with diabetic rats (+ve control) . 


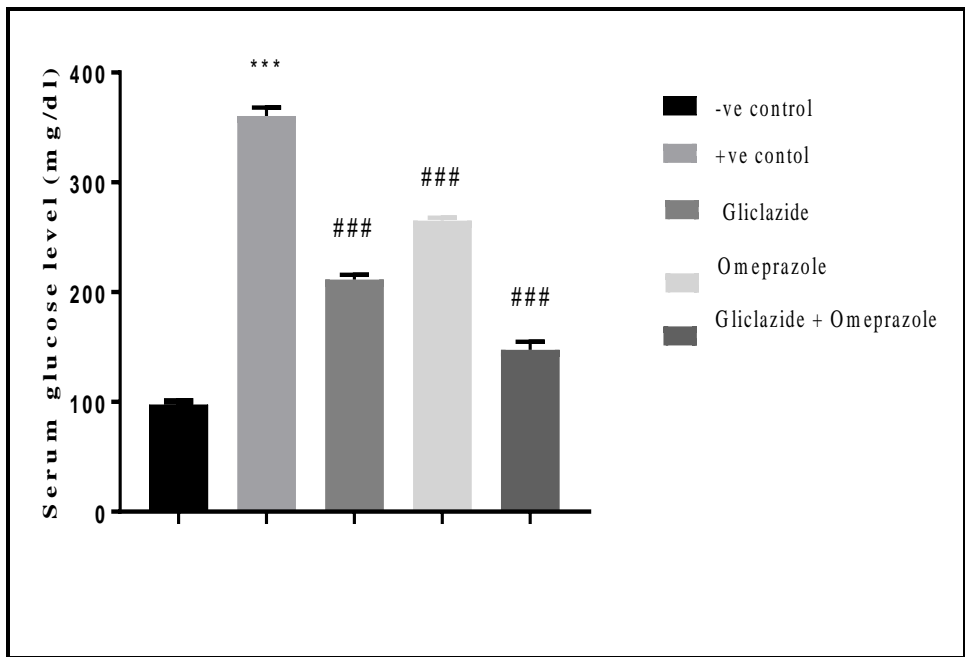

Figure (1): Effect of gliclazide $(10 \mathrm{mg} / \mathrm{kg})$, omeprazole $(20 \mathrm{mg} / \mathrm{kg})$ and their combination on serum glucose level of diabetic rats.

Data represents the mean \pm SE of each group $(n=8)$.

***: significant difference at $\mathrm{p}<0.001$ in comparison with $-\mathrm{ve}$ control.

\#\#\#: significant difference at $\mathrm{p}<0.00$ in comparison with diabetic rats (+ve control).

2- Effect of gliclazide, omeprazole and their combination on serum insulin level of diabetic rats:

These results are given in Table (1) and graphically illustrated in Figure (2).

The results showed that, serum insulin level was significantly decreased $(\mathrm{p}<0.001)$ in diabetic rats in comparison with - ve control rats.

In diabetic rats treated with gliclazide $10 \mathrm{mg} / \mathrm{kg}$ orally for 28 consecutive days, serum insulin level was significantly increased $(\mathrm{p}<0.001)$ in comparison with diabetic rats.

On the other hand, serum insulin level in diabetic rats treated with omeprazole $20 \mathrm{mg} / \mathrm{kg}$ orally for 28 consecutive days was significantly increased ( $\mathrm{p}<$ $0.001)$ in comparison with diabetic rats.

In diabetic rats treated with a combination of gliclazide $10 \mathrm{mg} / \mathrm{kg}$ and omeprazole $20 \mathrm{mg} / \mathrm{kg}$ orally for 28 consecutive days, serum insulin level was significantly increased $(\mathrm{p}<0.001)$ in comparison with diabetic rats.

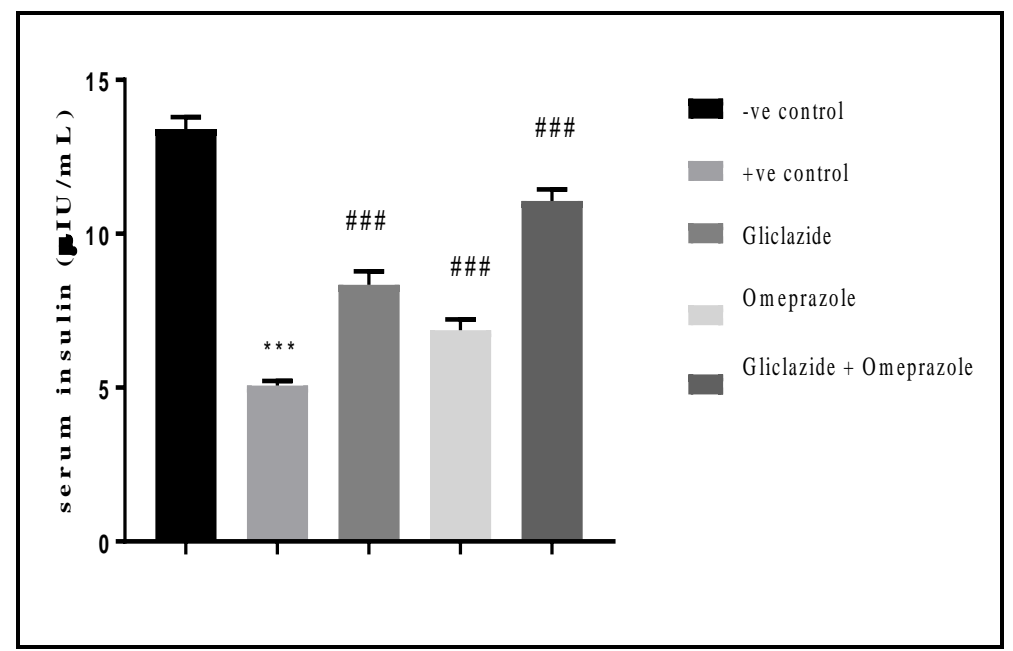

Figure (2): Effect of gliclazide $(10 \mathrm{mg} / \mathrm{kg})$, meprazole $(20 \mathrm{mg} / \mathrm{kg})$ and their combination on serum insulin level of diabetic rats.

Data represents the mean \pm SE of each group $(n=8)$.

$* * *$ : significant difference at $\mathrm{p}<0.001$ in comparison with $-\mathrm{ve}$ control .

\#\#\#: significant difference at $\mathrm{p}<0.001$ in comparison with diabetic rats (+ve control).

3- Effect of gliclazide, omeprazole and their combination on serum TAC of diabetic rats:

These results are given in Table (1) and graphically illustrated in Figure (3).
The results showed that, serumTAC was significantly decreased $(p<0.001)$ in alloxan-induced diabetic rats (+ve control) in comparison with -ve control rats. 
In diabetic rats treated with gliclazide $10 \mathrm{mg} / \mathrm{kg}$ orally for 28 consecutive days, serumTAC was significantly increased $(\mathrm{p}<0.001)$ in comparison with untreated diabetic rats (+ve control).

On the other hand, serum TAC in diabetic rats treated with omeprazole $20 \mathrm{mg} / \mathrm{kg}$ orally for 28 consecutive days was significantly increased $(\mathrm{p}<0.001)$ in comparison with untreated diabetic rats.

In diabetic rats treated with a combination of gliclazide $10 \mathrm{mg} / \mathrm{kg}$ and omeprazole $20 \mathrm{mg} / \mathrm{kg}$ orally for 28 consecutive days, serumTAC was significantly increased $(\mathrm{p}<0.001)$ in comparison with untreated diabetic rat.

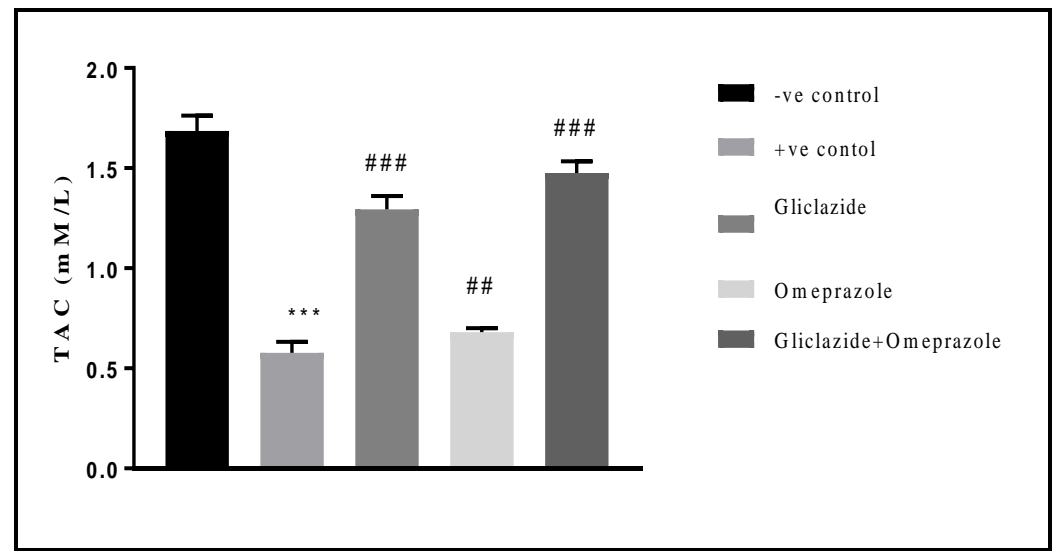

Figure (3): Effect of gliclazide $(10 \mathrm{mg} / \mathrm{kg})$, omeprazole $(20 \mathrm{mg} / \mathrm{kg})$ and their combination on serum TAC of diabetic rats.

Data represents the mean \pm SE of each group $(n=8)$.

$* * *$ : significant difference at $\mathrm{p}<0.001$ in comparison with $-\mathrm{ve}$ control.

\#\#\#: significant difference at $p<0.001$ in comparison with + ve control.

4- Effect of gliclazide, omeprazole and their combination on serum TNF-a level in diabetic rats.

These results are given in Table (1) and graphically illustrated in Figure (4).

The results showed that, serum TNF- $\alpha$ was significantly increased $(\mathrm{p}<0.001)$ in alloxan-induced diabetic rats (+ve control) in comparison with $-\mathrm{ve}$ control rats.

In diabetic rats treated with gliclazide $10 \mathrm{mg} / \mathrm{kg}$ orally for 28 consecutive days, serum TNF- $\alpha$ was significantly decreased $(\mathrm{p}<0.001)$ in comparison with untreated diabetic rats (+ve control).

On the other hand, serum TNF- $\alpha$ in diabetic rats treated with omeprazole $20 \mathrm{mg} / \mathrm{kg}$ orally for 28 consecutive days was significantly decreased ( $\mathrm{p}<$ $0.001)$ in comparison with untreated diabetic rats (+ve control).

In diabetic rats treated with a combination of gliclazide $10 \mathrm{mg} / \mathrm{kg}$ and omeprazole $20 \mathrm{mg} / \mathrm{kg}$ orally for 28 consecutive days, serum TNF- $\alpha$ was significantly increased $(\mathrm{p}<0.001)$ in comparison with untreated diabetic rats (+ve control).

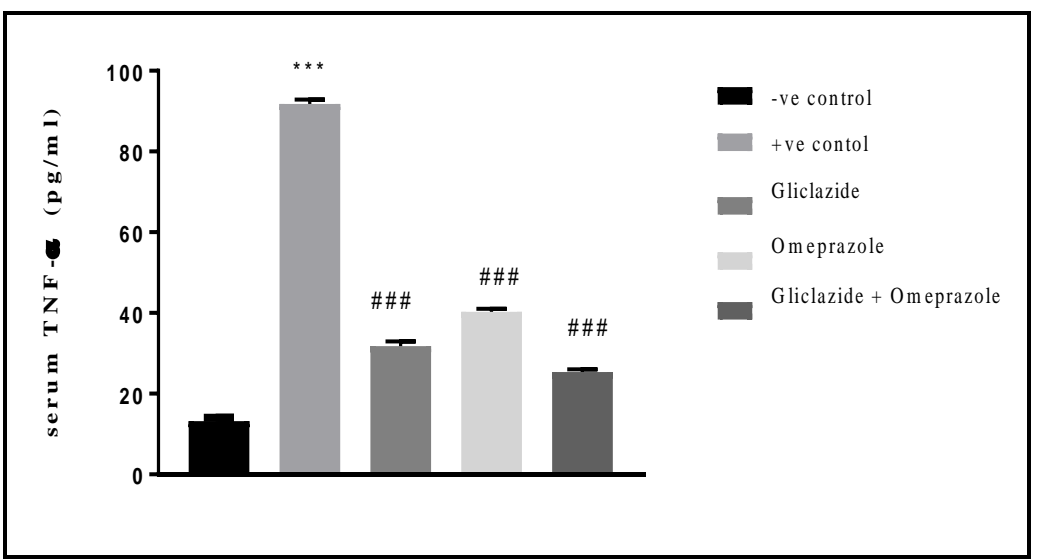

Figure (4): Effect of gliclazide $(10 \mathrm{mg} / \mathrm{kg})$, omeprazole $(20 \mathrm{mg} / \mathrm{kg})$ and their combination on TNF $\alpha$ of diabetic rats.

Data represents the mean \pm SE of each group $(n=8)$.

$* * *$ : significant difference at $\mathrm{p}<0.001$ in comparison with $-\mathrm{ve}$ control.

\#\#\#: significant difference at $\mathrm{p}<0.001$ in comparison with $+\mathrm{ve}$ control. 
5- Effect of gliclazide, omeprazle and their combination on histopathological changes of pancreatic tissues in diabetic rats:

Examined sections of pancreas of -ve control rats showed the normal histopathological structure of $\beta$ cells at the islets of Langerhans and normal pancreatic acini (Figure 5A). The pancreas of alloxan-induced diabetic rats showed damaged $\beta$-cells due to necrosis leading to decreased its number and degeneration of pancreatic acini (Figure 5B).
Diabetic rats treated with gliclazide revealing regenerating $\beta$-cells and pancreatic acini (Figure 5C). Examined sections of the pancreas of diabetic rats treated with omeprazole showed an increase number of $\beta$-cells with mild hyalinosis of some $\beta$-cells and normal acini (Figure 5D). The pancreas of diabetic rats treated with combination of gliclazide and omeprazole showed nearly normal histopathological structure of $\beta$-cells at the islets of Langerhans and normal pancreatic acini (Fiure 5E).
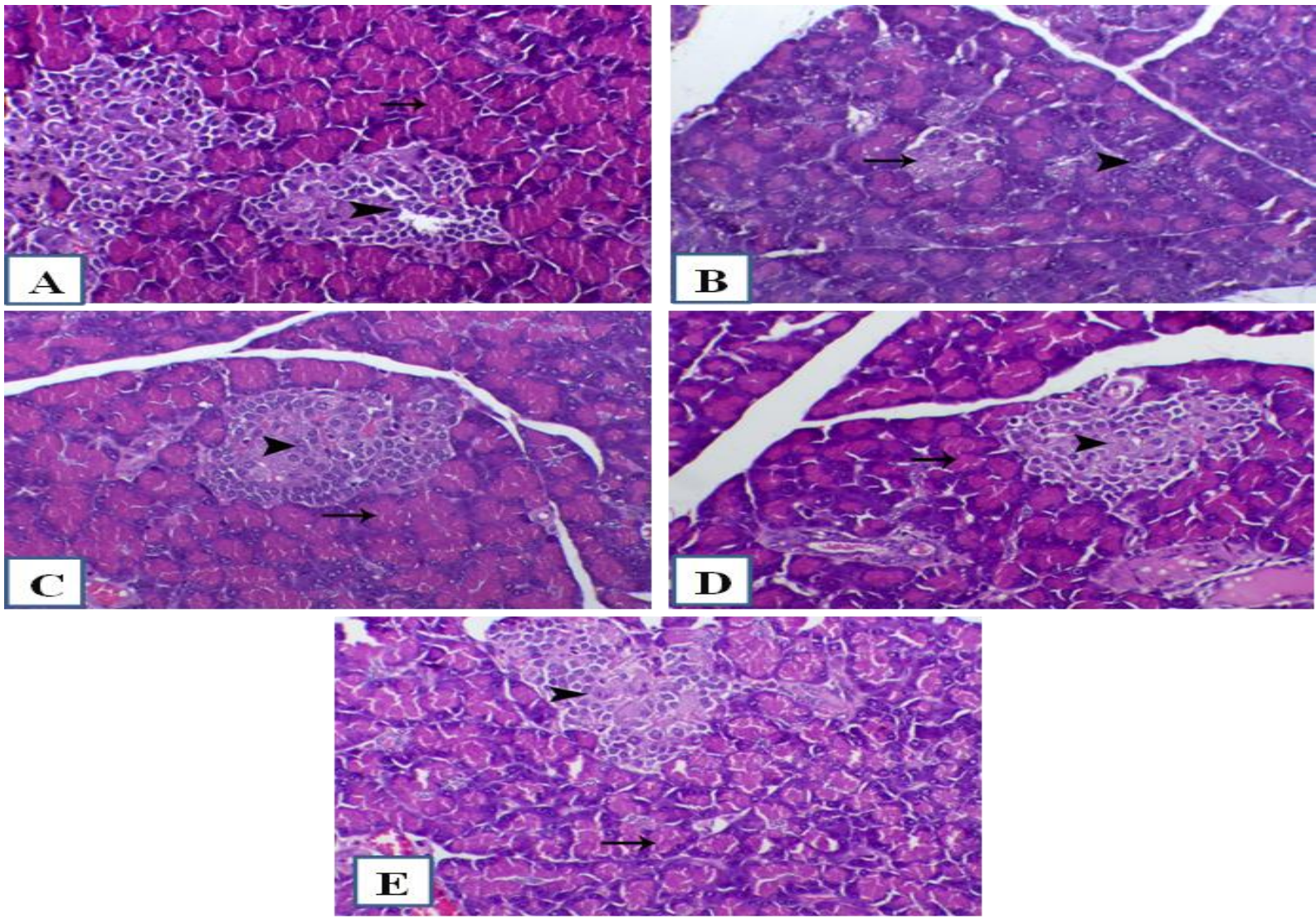

Figure (5): Histopathological changes in pancreatic tissue from rats of the studied groups x200:

A) -ve control rats showed the normal histopathological structure of $\beta$-cells in the islets of Langerhans (arrowhead) and normal pancreatic acini (arrow) H\&E, X200. B) Alloxan-induced diabetic rats showed damaged $\beta$-cells due to necrosis leading to decreased its number (arrow) and degeneration of pancreatic acini (arrowhead) H\&E, X200. C) Diabetic rats treated with gliclazide revealing regenerating $\beta$-cells (arrow head) and pancreatic acini (arrow) H\&E, X200. D) Diabetic rats treated with omeprazole showed an increase number of $\beta$-cells with mild hyalinosis of some $\beta$-cells (arrowhead) and normal acini (arrow) H\&E, X200. E) Diabetic rats treated with a combination of gliclazide and omeprazole showed nearly normal histopathological structure of $\beta$-cells at the islets of Langerhans (arrowhead) and normal pancreatic acini (arrow) H\&E, X200.

\section{DISCUSSION}

Experimental DM was induced, according to Mastan et al. (2009) by injecting of alloxan monohydrate $100 \mathrm{mg} / \mathrm{kg}$ IP as a single dose. Alloxan monohydrate induces diabetes by destroying the insulin-producing $\beta$-cells of the pancreas (Oberley, 1988). This action is mediated by ROS with a simultaneous massive increase in intracellular calcium concentration leading to a rapid destruction of $\beta$ cells (Szkudelski, 2001).
As regarding serum glucose level, results of this study showed that serum glucose level significantly increased in alloxan-induced diabetic rats in comparison with -ve control rats. This reults are consistent with Mastan et al. (2009).

The present study investigated that serum glucose level was significantly decreased in diabetic rats treated with gliclazide $10 \mathrm{mg} / \mathrm{kg}$ for 28 consecutive 
days, in comparison with diabetic rats. This was similar to results reported by Agrawal and Gupta (2013) who reported that gliclazide has a glucose lowering effect in diabetic rats.

Gliclazide is a second generation sulfonylurea and it acts on $\beta$-cells of pancreas and stimulate insulin secretion by reducing the permeability of $\mathrm{K}^{+}$ion channels. In addition, it increases the sensitivity of peripheral tissue to insulin and reduces insulin resistance (Nasry et al., 2013).

Treatment of diabetic rats with omeprazole $20 \mathrm{mg} / \mathrm{kg}$ for 28 consecutive days cause significant reduction in serum glucose level in comparison with diabetic rats. This results similar to recent retrospective electronic medical record examination indicated that patients with T2DM taking PPIs (omeprazole, esomeprazole, pantoprazole, rabeprazole or lansoprazole) showed improved glycaemic control compared with a group of patients not taking a PPIs (Lin et al., 2016).

The explanation is PPIs have been shown to increase endogenous gastrin levels in animals and humans. It has also been suggested that gastrin may exert functional role in stimulating insulin secretion which in turn is responsible for its hypoglycemic effect (Takebayashi and Inukai, 2015).

This study indicated that gliclazide at $10 \mathrm{mg} / \mathrm{kg}$ or omeprazole at $20 \mathrm{mg} / \mathrm{kg}$ was to some extent reduce the serum glucose level, while serum glucose level was pointedly decreased with a combination of gliclazide $10 \mathrm{mg} / \mathrm{kg}$ and omeprazole $20 \mathrm{mg} / \mathrm{kg}$ indicating that interaction of PPIs with antidiabetic occurred by therapeutic doses. This is in accordance with previous study of kumar et al. (2000) that reported that omeprazole significantly enhanced the hypoglycaemic activity of sulfonylureas in albino rabbits.

The literature reports reveal that sulfonylureas are metabolized mainly by CYP2C9 and CYP3A. PPIs probably inhibits CYP isoenzymes that are responsible for metabolism of sulfonylureas. It may be concluded that during concomitant administration of sulfonylureas and omeprazole at therapeutic doses, drug-drug interaction does occur (Schelleman et al., 2014).

In disagree with this results, Mrudula et al. (2017) reported that in vivo studies conducted on alloxaninduced diabetic rats showed that there are no interactions at therapeutic doses with PPIs but at higher doses it enhanced the anti-diabetic potential of sulfonylureas like glipizide and glibenclamide. They explained that sulfonylureas are mainly metabolized by CYP3A4 and CYP2C9, the weak inhibitory effect of the PPI's on the same enzyme shows significant interaction only at higher doses, but is safe to be administered concomitantly at therapeutic doses.
As regarding insulin, the present study noted that serum insulin level was significantly decreased in diabetic rats in comparison with -ve control rats. This reults are consistent with Ryle et al. (1984).

Sustained hyperglycemia has been identified as a principle mediator of increased ROS generation in diabetes (Santakumari et al., 2003). This might be the result of suppression of $\beta$-cell proliferation and inhibition of insulin gene transcription (Robertson et al., 2003) that caused impairment of insulin release.

Data of the present investigation showed that gliclazide significantly increase the serum insulin level, same as the study conducted by Dachicourt et al. (1998) who have examined the effects of gliclazide treatment on the severity of diabetes in rats. In the gliclazide-treated rats, plasma glucose levels declined progressively and their insulin levels decreased to values similar to those in non-diabetic rats. They concluded that gliclazide improves $\beta$-cell function through improvement of the insulin content per individual $\beta$-cell. sulfonylurea is a direct insulin secrectagogue; indirectly it also increase insulin secretion in response to fuels such glucose (Röder et al., 2016).

In diabetic rats treated with omeprazole, serum insulin level was significantly increased in comparison with diabetic rats. There results are similar to the results of Bödvarsdóttir et al. (2010) who showed that the PPIs increase endogenous gastrin levels and insulin content of the pancreas and the level of insulin in the blood are increased.

In contrast, no differences in glucose levels or insulin secretion were found in another study that examined the effects of treatment with PPIs in patients with T2DM, despite a 9-fold increase in endogenous gastrin levels (Dupre et al., 1969).

Data of the current study revealed that combined administration of gliclazide and omeprazole cause significant increase in serum insulin levels in comparison with diabetic rats. The percent of increase is more than each single administration. In agreement with this results, Phadatare et al. (2011) stated that Sulfonylurea and PPIs combination therapy produced hypoglycemia or antihyperglycemia and increased the serum insulin level in normal and diabetic rats.

Sulfonylurea produced hypoglycemia in normal/ diabetic rats, omeprazole is metabolized by hepatic CYP2C19 and CYP3A4 and there is more possibility that omeprazole inhibit the metabolism of gliclazide, which is metabolized by CYP3A4 and CYP2C9 (Gökalp et al., 2011). Furthermore, the presence of interaction was supported by an increase in serum insulin levels with omeprazole treatment. 
As redarding TAC, The present data showed that serum TAC was significantly decreased in alloxaninduced diabetic rats in comparison with -ve control rats. This finding further supports and thus confirms the previous result that diabetes is associated with impaired antioxidant defences (Vicentini et al., 2011). The results of the present study corroborate the finding that shows a decline in the activities of antioxidant enzymes in diabetic rats (Das and Sil, 2012).

During diabetic state, increased generation of ROS occur and cause an imbalance between the oxidant and antioxidant status (Noda et al., 2000).

The marked increase in serum TAC level noticed in this study in the diabetic rats treated with gliclazide, is in accordance with Mourya et al. (2018) who reported that administration gliclazide to patients with T2DM resulted in an increase in the antioxidant parameters, TAC, MDA, SOD and thiols.

Data of the current study showed that administration of omeprazole to diabetic rats significantly increased TAC in comparison with untreated diabetic rats. There results were similar to that of previous authors Abdelzaher et al. (2017) who reported that omeprazole significantly improved tissue oxidative stress parameters (MDA, CAT, SOD, NO) in diabetic rats compared to the non-treated diabetic rats.

Biswas and his workers (2003) stated that PPIs exhibit anti-oxidant effects of ROS by blocking membrane lipid peroxidation and protein oxidation, omeprazole have gastro-protective effects via inhibition of oxidative tissue damage and a direct scavenging activity against the hydroxyl radical.

In the present study, the elevated serum TNF- $\alpha$ level in diabetic rats, is in accordance with Swaroop et al. (2012) who recently reported that uncontrolled diabetes significantly enhanced TNF- $\alpha$ level.

Inflammatory cytokines as TNF- $\alpha$ has been involved in the pathogenesis of DM (Lushchak et al., 2018), it catalyzes multiple signaling cascades which resulted in $\beta$-cell apoptosis. TNF- $\alpha$ destroy the pancreatic $\beta$ cells and created DM via enhancing the formation of free radicals, lipid peroxides and aldehydes (ElHadidy et al., 2015).

The serum TNF $\alpha$ level was significantly decreased in diabetic rats treated with gliclazide in comparison with untreated diabetic rats. This observed decrease in TNF- $\alpha$ level is in agreement with the findings of Mourya et al. (2018) who found that the administration of gliclazide in patient with T2DM inhibit the enhanced production of TNF- $\alpha$.

This could be attributed to that gliclazide possesses a unique azabicyclo-octyl ring act as a general free radical scavenger (Palsamy and Subramanian, 2010) which inhibit TNF- $\alpha$ production (Drzewoski and Zurawska-Klis, 2006). TNF- $\alpha$ exacerbate diabetic complications by promoting tissue ischemia so, suppression of increased TNF- $\alpha$ may ameliorate diabetic complications (Yan et al., 2018).

Administration of omeprazole to diabetic rats significantly decreased the level of TNF- $\alpha$, this result is in accordance with the study of Abdelzaher et al. (2017) who reported that omeprazole significantly decreased the level of serum $\mathrm{TNF} \alpha$ in diabetic rats and the work of Onda et al., 2017 who showed that PPIs decreased cytokine secretion.

The histopathological data of this study also support the results of biochemical markers. In pancreas of alloxan-induced diabetic rats, There were atrophy and necrosis of $\beta$-cells and decreasing in $\beta$-cells number. These data were in agreement with Shah and Khan (2014) and El-Esawy et al. (2016) who demonstrated that diabetic rats show damaged $\beta$ cells due to necrosis and a decreased number of $\beta$ cells and Yagihashi (2017) who reported that $\beta$-cell mass is reduced in diabetic patients.

Alloxan induces hyperglycemia by specific cytotoxic impact on pancreatic $\beta$-cells leading to its damage. One of the intracellular phenomena for its cytotoxicity is through the production of free radicals (Yadav et al., 2002).

Treatment of diabetic rats with gliclazide showed a significant protection of islets of Langerhans and acinar cells in comparison to that of the diabetic group. Our results are similar to the results of Kimoto et al. (2003) who demonstrated that gliclazide could protect pancreatic $\beta$-cells from oxidative damage. Thier results suggest that gliclazide reduces oxidative stress of beta-cells by $\mathrm{H}_{2} \mathrm{O}_{2}$ probably due to its radical scavenging activity and results of Parim et al. (2016) who investigated that treatment of diabetic rats with gliclazide lead to regeneration of $\beta$-cells.

The present information expresses that omeprazole showed significant reduction of histopathological changes and increased $\beta$-cells number in comparison with diabetic rats. This results similar to the results of Beamish et al. (2017) who reported that PPIs lead to endogenous hypergastrinaemia. Gastrin has been shown to promote beta-cell proliferation in rodents. Also, Rooman et al. (2002) noticed an increase in the number of single, extra-insular $\beta$-cells and small betacell clusters after gastrin treatment following pancreatic duct ligation in rats, suggesting increased $\beta$-cell neogenesis.

However, this showed disagreement with the results reported by the study of Breuer et al. (2016) who showed that PPIs treatment was not associated with 
changes in glucose control, islet morphology or new $\beta$-cell formation.

\section{CONCLUSION}

Finally, it can be concluded that, in the treatment of DM associated with peptic ulcer, application of antidiabetic agent gliclazide in combination with omeprazole would have drug-drug interaction. The antidiabetic action of gliclazide was enhanced by omeprazole as regard our data obtained by laboratory and histopathological results.

\section{REFERENCES}

Abdel Aziz, M.A.; Badary, D.M. and Hussein, M.A. (2017): Renal damage following Alloxaninduced diabetes is associated with generation of reactive oxygen species, alterations of p53, TGF- $\beta 1$ and extracellular matrix metalloproteinases in rats. Cell biology international, 41, 525-533.

Abdelzaher, Y.; Labib, A.A. and Toni, D.M. (2017): The Role of Zileuton in IndomethacinInduced Gastric Ulceration in Pyloric- Ligated Diabetic Rats. Egyptian journal of basic and clinical pharmacology, 7, 1-13.

Agrawal, N.K. and Gupta, U. (2013): Evaluation of ramipril on blood sugar level and interaction with the oral anti-diabetic drugs in alloxaninduced diabetic rats. Internal Journal of Pharmceutical Science Research, 4, 29332938.

Alshammari, J.H.; ALI, M.B.; Bashantoof, S.K.; Qalib, Z.A.; Al-Amri, B.Z.; Alrwely, H.H.; Alamri, S.Z.S.; Alharbi, A.S.S. and Alfallaj, E.H.O. (2018): Peptic Ulcer Disease in Elderly Population of Arar City, Northern Saudi Arabia. Egyptian Journal of Hospital Medicine, 73, 6494-6501.

Beamish, C.A.; Zhang, L.; Szlapinski, S.K.; Strutt, B.J. and Hill, D.J. (2017): An increase in immature beta-cells lacking Glut2 precedes the expansion of beta-cell mass in the pregnant mouse. PLoS One, 12, 1-15.

Beyaert, R. and Fiers, W. (1998): Tumor necrosis factor and lymphotoxin. Journal of cell biology, 143, 2057-2065.

Biswas, K.; Bandyopadhyay, U.; Chattopadhyay, I.; Varadaraj, A.; Ali, E. and Banerjee, R.K. (2003): A novel antioxidant and antiapoptotic role of omeprazole to block gastric ulcer through scavenging of hydroxyl radical. Journal of Biological Chemistry, 278, 1099311001.

Bödvarsdóttir, T.B; Hove, K.D and Gotfredsen, C.F (2010): Treatment with a proton pump inhibitor improves glycaemic control in Psammomys obesus, a model of type 2 diabetes. Diabetologia, 53, 2220-2223.
Breuer, T.G.; Borker, L.; Quast, D.R.; Tannapfel, A.; Schmidt, W.E.; Uhl, W. and Meier, J.J. (2016): Impact of proton pump inhibitor treatment on pancreatic beta-cell area and beta-cell proliferation in humans. European Journal Endocrinology, 175, 467-476.

Dachicourt, N.; Bailbé, D.; Gangnerau, M.N.; Serradas, P.; Ravel, D. and Portha, B. (1998): Effect of gliclazide treatment on insulin secretion and $\beta$-cell mass in non-insulin dependent diabetic Goto-Kakisaki rats. European journal of pharmacology, 361, 243251.

Das, J. and Sil, P.C. (2012): Taurine ameliorates alloxan-induced diabetic renal injury, oxidative stress-related signaling pathways and apoptosis in rats. Amino acids, 43, 15091523.

D Bancroft, J. and Stevens, A. (2018): Theory and practice of histological techniques./ edited by John D. Bancroft, Alan Stevens, 2008.

Drzewoski, J. and Zurawska-Klis, M. (2006): Effect of gliclazide modified release on adiponectin, interleukin-6, and tumor necrosis factor- $\alpha$ plasma levels in individuals with type 2 diabetes mellitus. Current Medical Research and Opinion, 22,1921-1926.

Dupre, J.; Curtis, J.D.; Unger, R.H.; Waddell, R.W. and Beck, J.C. (1969): Effects of secretin, pancreozymin, or gastrin on the response of the endocrine pancreas to administration of glucose or arginine in man. The Journal of clinical investigation, 48, 745-757.

El-Esawy, B.H.; Alghamdy, A.N.; El Askary, A. and Elsayed, E.M. (2016): Histopathological evaluation of the pancreas following administration of paricalcitol in alloxaninduced diabetic wistar rats. World. J. Pharm. Pharmac. Sci., 5, 189-198.

El-Hadidy, W.F.; Mohamed, A.R. and Mannaa, H.F. (2015): Possible protective effect of procainamide as an epigenetic modifying agent in experimentally induced type 2 diabetes mellitus in rats. Alexandria Journal of Medicine, 51, 65-71.

Gökalp, O.; Gunes, A.; Çam, H.; Cure, E.; Aydin, O.; Tamer, M.N.; Scordo, M.G. and Dahl, M.L. (2011): Mild hypoglycaemic attacks induced by sulphonylureas related to CYP2C9, CYP2C19 and CYP2C8 polymorphisms in routine clinical setting. European journal of clinical pharmacology, 67, 1223-1229.

Hussein, A.; Abdel-Mageid, A. and Abu-Ghazalla, A.M. (2015): Biochemical study on the effect of alpha-lipoic acid on lipid metabolism of rats fed high fat diet. Banha Veterinary Medicine Journal, 28, 109-119.

Ige, O. and Adewoye, O. (2013): Gastroprotective Effect of Magnesium on Indomethacininduced Gastric Ulceration in Normal and 
Alloxan Induced-Diabetic Rats. African Journal of Biomedical Research, 16, 125-132.

Inzucchi, S.E.; Bergenstal, R.M.; Buse, J.B.; Diamantnnini, E.; Nauck, M.; Peters, A.L.; Tsapas, A.; Wender, R. and Matthews, D.R. (2012): Management of hyperglycaemia in type 2 diabetes: a patient-centered approach. Position statement of the American Diabetes Association (ADA) and the European Association for the Study of Diabetes (EASD). Diabetologia, 55, 1577-1596.

Jay, D.; Hitomi, H. and Griendling, K.K. (2006): Oxidative stress and diabetic cardiovascular complications. Free Radical Biology and Medicine, 40, 183-192.

Kandhare, A.D.; Raygude, K.S.; Ghosh, P.; Ghule, A.E. and Bodhankar, S.L. (2012): Neuroprotective effect of naringin by modulation of endogenous biomarkers in streptozotocin induced painful diabetic neuropathy. Fitoterapia, 83, 650-659.

Kimoto, K.; Suzuki, K.; Kizaki, T.; Hitomi, Y.; Ishida, H.; Katsuta, H.; Itoh, E.; Ookawara, T.; Suzuki, K.; Honke, K. and Ohno, H. (2003): Gliclazide protects pancreatic beta-cells from damage by hydrogen peroxide. Biochemicl and Biophysical Research Communications, 303, 112-119.

Koracevic, D.; Koracevic, G.; Djordjevic, $\quad$.; Andrejevic, S. and Cosic, V. (2001): Method for the measurement of antioxidant activity in human fluids. Journal clinical pathology, 54, 356-361.

Kumar, V.; Venkat Rao, N. and Siddamsetty, R.S. (2000): Influence of omeprazole on hypoglycaemic activity of glibenclamide and tolbutamide in normal albino rabbits. Acta Pharmaceutica Turcica, 4, 135-138.

Lin,C.; Hsiao, T.; Lin, L.; Uang, S.; Cheng, W.; Wang, Y. and Wang, H. (2016): The use of proton pump inhibitors decreases the risk of diabetes mellitus in patients with upper gastrointestinal disease: a population-based retrospective cohort study. Medicine, 95, 4195-4199.

Lushchak, O.; Zayachkivska, A. and Vaiserman, A. (2018): Metallic Nanoantioxidants as Potential Therapeutics for Type 2 Diabetes: A Hypothetical Background and Translational Perspectives. Oxidative medicine and cellular longevity, 2018, 1-9.

Mastan, S.; Thirunagari, L.; Sri Latha, T.; Srikanth, A.; Chaitanya, G. and Kilari, E. (2009): Influence of methanolic extract of Syzygium cumini seeds on the activity of gliclazide in normal and alloxan-induced diabetic rats. Pharmacologyonline, 3, 845-850.

Mastan, K. and Kumar, E. (2010): Influence of atazanavir on the pharmacodynamics and pharmacokinetics of gliclazide in animal models. International Journal of Diabetes Mellitus, 2, 56-60.

Morjan, S.; Al Laham, S. and Atieh, R. (2013): Gastroprotective efficacy of folic acid and omeprazole in indomethacin-induced gastropathy in rats. International Journal of Pharmacognosy and Phytochemical Research, $5,113-119$

Mourya, A.; Akhtar, A.; Ahuja, S.; Sah, S.P. and kumar, A. (2018): Synergistic action of ursolic acid and metformin in experimental model of insulin resistance and related behavioral alterations. European journal of Pharmacology, 835, 31-40.

Mrudula, G.; Caroline, P.; Kingsley, T. and Jaiswal $R$ (2017): A Review on Drug Interactions in Oral Hypoglycemic Drugs by Mechanism of Cytochrome P450 Enzyme Inhibition. Journal of Pharmceutical research, 16, 154-159.

Nasry, M.R.; Abo-Youssef, A.M. and Abd El-Latif, H.A. (2013): Anti-diabetic activity of the petroleum ether extract of Guar gum in streptozotocin-induced diabetic rats: A comparative study. Beni-Suef University Journal of Basic and Applied Sciences, 2, 5159.

Noda, Y.; Kneyuki, T.; Igarashi, K.; Mori, A. and Packer, L. (2000): Antioxidant activity of nasunin, an anthocyanin in eggplant peels. Toxicology, 148, 119-123.

Oberley, L.W. (1988): Free radicals and diabetes. Free radical biology and medicine, 5, 113124.

Onda, K.; Tong, S.; Beard, S.; Binder, N.; Muto, M.; Senadheera, S.N.; Parry, L.; Dilworth, M.; Renshall, L.; Brownfoot, F.; Hastie, R.; Tuohey, L.; Palmer, K.; Hirano, T.; Ikawa, M.; Kaitu'u-Lino, T. and Hannan, N.J. (2017): Proton Pump Inhibitors Decrease Soluble fmsLike Tyrosine Kinase-1 and Soluble Endoglin Secretion, Decrease Hypertension, and Rescue Endothelial Dysfunction. Hypertension, 69, 457-468.

Owu, D.U.; Obembe, A.O.; Nwokocha, C.R.; Edoho, I.E. and Osim, E.E. (2012): Gastric ulceration in diabetes mellitus: protective role of vitamin C. ISRN gastroenterology, 2012, 1-7.

Palsamy, $\quad$. and Subramanian, S. (2010): Ameliorative potential of resveratrol on proinflammatory cytokines, hyperglycemia mediated oxidative stress, and pancreatic $\beta$ cell dysfunction in streptozotocinnicotinamide-induced diabetic rats. Journal of cellular physiology, 224, 423-432.

Parim, B.; Uddandrao, V.V.S.; Ravindarnaik, R.; Pothani, S.; Munipally, K.; Meriga, B.; Begum, S.; Varatharaju, C.; Rajesh, P. \& Saravanan, G. (2016): Effects of SAllylcysteine on Biomarkers of the Polyol Pathway in Rats with Type 2 Diabetes. Can J Diabetes, 40, 442-448. 
Phadatare, P.D. and Chandrashekhar, V. (2011): Influence of esomeprazole on hypoglycemic activity of oral antidiabetic agents in rats and rabbits. Molecular and cellular biochemistry, 354, 135-140.

Robertson, R.P.; Harmon, J.; Tran, P.O.; Tanaka, Y. and Takahashi, H. (2003): Glucose toxicity in $\beta$-cells: type 2 diabetes, good radicals gone bad, and the glutathione connection. Diabetes, 52, 581-587.

Röder, P.V.; Wu, B.; Liu, Y. and Han, W. (2016): Pancreatic regulation of glucose homeostasis. Experimental \& molecular medicine, 48, 201219.

Rooman, I.; Lardon, J. and Bouwens, L. (2002): Gastrin stimulates beta-cell neogenesis and increases islet mass from transdifferentiated but not from normal exocrine pancreastissue. Diabetes, 51, 686-690.

Ryle, P.R.; Barker, J.; Gaines, P.A.; Thomson, A.D. and Chakraborty, J. (1984): Alloxan-induced diabetes in the rat - protective action of (-) epicatechin?. Life Sci, 34, 591-595.

Santakumari, P.; Prakasam, S. and Pugalendi, K. (2003): Modulation of oxidative stress parameters by treatment with Piper betel in STZ induced diabetic rats. Indian Journal of Pharmacology, 35, 373-378.

Schelleman, H.; Han, X.; Brensinger, C.M.; Quinney, S.K.; Bilker, W.; Flockhart, D.A.; Li, L. and Hennessy, S. (2014): Pharmacoepidemiologic and in vitro evaluation of potential drug-drug interactions of sulfonylureas with fibrates and statins. British journal of clinical pharmacology, 78, 639-648.

Shah, N.A. and Khan, M. R. (2014): Antidiabetic effect of Sida cordata in alloxan induced diabetic rats. BioMed research international, 2014.

Swaroop, J.J.; Rajarajeswari, D. and Naidu, J. (2012): Association of TNF- $\alpha$ with insulin resistance in type 2 diabetes mellitus. The Indian journal of medical research, 135, 127130.
Szkudelski, T. (2001): The mechanism of alloxan and streptozotocin action in B cells of the rat pancreas. Physiological research, 50, 537-546.

Takebayashi, K. and Inukai, T. 2015): Effect of proton pump inhibitors on glycemic control in patients with diabetes. World journal of diabetes, 6, 1122-1131.

Takehara, K.; Tashima, K. and Takeuchi, K. (1997) Alterations in duodenal bicarbonate secretion and mucosal susceptibility to acid in diabetic rats. Gastroenterology, 112, 418-428.

Trinder, P. (1969): Determination of blood glucose using an oxidase-peroxidase system with a non-carcinogenic chromogen. Journal of clinical pathology, 22(2), 158-161.

Tseng, P.H.; Lee, Y.C.; Chiu, H.M.; Chen, C.C.; Liao, W.C.; Tu, C.H.; Yang, W.S. and Wu, M.S. (2012): Association of diabetes and HbA1c levels with gastrointestinal manifestations. Diabetes care, 35, 1053-1060.

Vicentini, J.; Valentini, J.; Grotto, D.; Paniz, C.; Roehrs, M.; Brucker, N.; Charão, F.; Moro, M.; Tonello, R. and Moreira, A.L. (2011): Association among microalbuminuria and oxidative stress biomarkers in patients with type 2 diabetes. Journal of Investigative Medicine, 59, 649-654.

Yadav, S.; Vats, V.; Dhunnoo, Y. and Grover, J. (2002): Hypoglycemic and antihyperglycemic activity of Murraya koenigii leaves in diabetic rats. Journal of Ethnopharmacology, 82, 111116.

Yagihashi, S. (2017): Diabetes and pancreas size, does it matter? Journal of diabetes investigation, 8, 413-415.

Yan, L.; Zheng, D. and Xu, R. (2018): Critical role of TNF signaling in mesenchymal stem cellbased therapy for autoimmune and inflammatory diseases. Frontiers in immunology, 9, 1-13.

Zhang, M.; Lv, X.Y.; Li, J.; Xu, Z.G. and Chen L. (2008) The Characterization of High-Fat Diet and Multiple Low-Dose Streptozotocin Induced Type 2 Diabetes Rat Model. Experimental Diabetes Research, 2008, 1-9. 


\section{تعزيز لتاثير الجليكلازيد كمضاد لمرض السكر بواسطة الأوميبرازول كمضاد للقرحة المعدية فى الفئران المصابة بمرض السكرى الناجم عن الألوكسان \\ محمود حدى عبد الرحيم ، صفوت عبل ألهادى منقورة ، سطوحى أحداء سطوحى ، سارى خليل عبد الغفار،}

E-mail: asmaamsadek92@gmail.com Assiut University web-site: www.aun.edu.eg

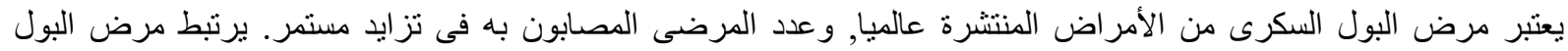

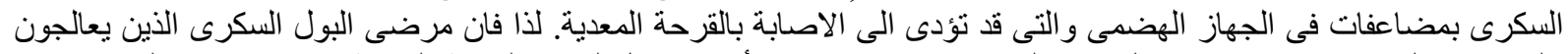

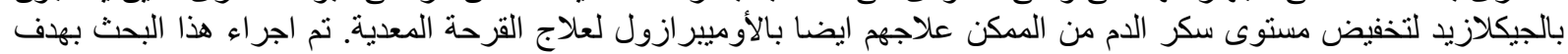

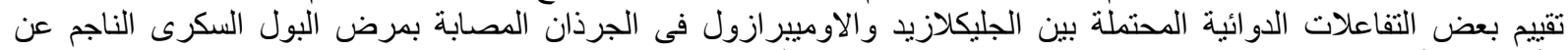

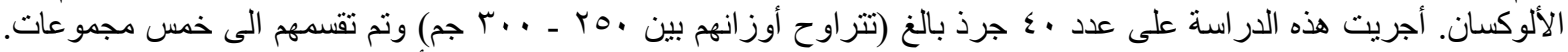

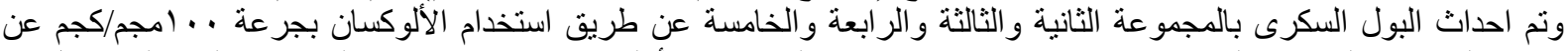

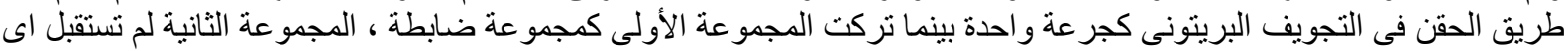

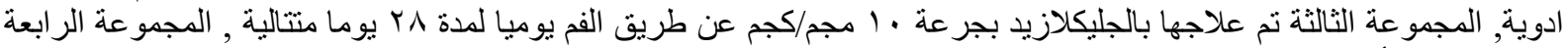

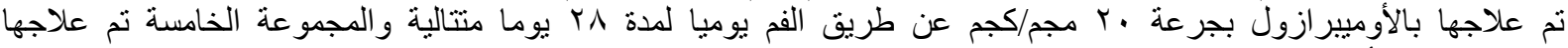

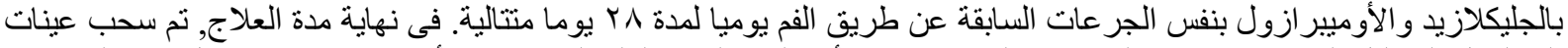

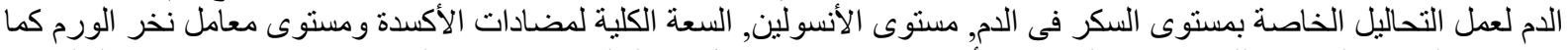

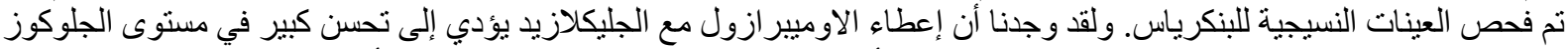

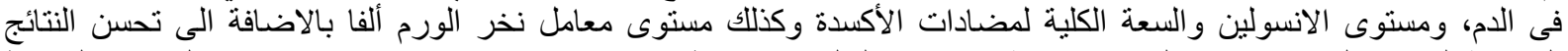

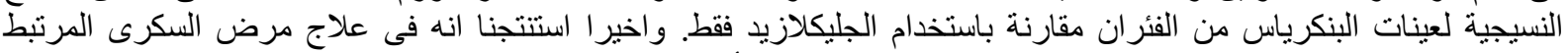

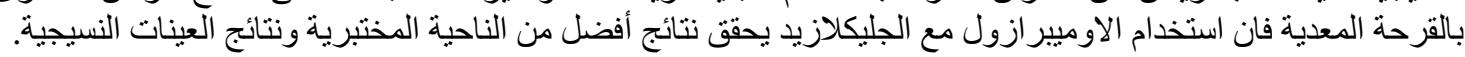

